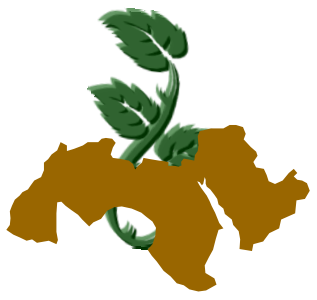

\title{
MANAGEMENT OF BROWN ROT DISEASE OF POTATO
}

\author{
Mahmoud ${ }^{1}$, S.M. \\ 1- Plant Path. Res. Instit., Agric. Res. Centre, Giza, Egypt
}

Keywords: Potato bacterial wilt, Resistance cultivars, Fertilizers, Biological control, Induced systemic resistance

\begin{abstract}
Different applications [various potato cultivars, chemical fertilizers, bioagents and chemical inducers] were used for controlling brown rot disease of potato. Potato cultivars namely Diamant, Desiree, Herms, Lady Joy, Lady Rossetta, Nicola, Spunta and Valor were variably susceptible to Ralstonia solanacearum, the causal pathogen of brown rot disease. Herms cultivar was the least susceptible. Application of ammonium sulfate, potassium sulfate, Urea, and calcium superphosphate to infested soil as a single amendment reduced disease incidence. Application of calcium superphosphate was the most effective treatment. The bioagents Pseudomonas fluorescens, Pseudomonas putida and Bacillus subtilis were effective in controlling disease when were used separately and Pseudomonas putida was the most efficient. Foliar spraying with different inducers singly [salicylic acid, di-potassium hydrogen phosphate and tri-potassium phosphate] reduced the disease incidence. Tri-potassium phosphate was the most effective against the disease. Therefore, a management programme was suggested including cultivar Herms, calcium superphosphate, Pseudomonas putida and tri-potassium phosphate, as integrated treatment. Rotation of these agents showed high effectiveness to disease control as well on the yield increase.
\end{abstract}

\section{INTRODUCTION}

Bacterial wilt [brown rot] disease caused by Ralstonia solanacearum is a serious obstacle to the culture of many solanaceous plants. The greatest economic damage has been reported on potato
[Lemaga et al 2001 and Milling et al 2004]. The disease is the principle cause for rejection of exported potato [Farag et al 1999].

Cultivation of resistant cultivars is considered one of the most effective procedures in integrated control programme of potato bacterial wilt diseases [Farag 1970 and 1976, Vasilieva 1998 and Wiles 2001].

It is believed that potato yield losses due to bacterial wilt is increased with decreasing soil fertility. The interaction between soil fertility and bacterial wilt incidence merits further studies in different environments [Lemaga et al 2001]. Application of chemical fertilizers as Urea, potassium sulfate and ammonium sulfate alone reduced the severity of potato bacterial wilt compared with the control [Abd El-Ghafar and Abd El-Sayed 2002].

Biological control has been found of immense potential in management of bacterial wilt of potato, whereas application of isolates of Bacillus subtilis, Pseudomonas putida and Ps. fluorescens singly as tuber treatment led to a decrease in the severity of the disease [Tawfik et al 2001].

Zayed et al 2004 studied the significance of inducing systemic resistance in potato against $R$. solanacearum. They found that application of dipotassium phosphate, tri-potassium phosphate and salicylic acid alone as foliar treatment at concentration of $1 \mathrm{mM}$ significantly reduced the disease incidence and increased yield.

The integrated disease control assumed to be the best method for management, increasing yield and reducing bactericide applications [Zayed $\boldsymbol{e t}$ al 2004].

Hence, the current study is aiming at evaluating how success could be gained by integrated disease management if using resistant cultivars, fertilizers, bioagents and inducers subsequently in one regime. 


\section{MATERIALS AND METHODS}

\section{Preparation of inoculum and soil infestation}

Virulent isolate of Ralstonia solanacearum was previously isolated from infected potato tubers identified by Farag et al 2006 and grown on nutrient agar plates for 24 hours at $29^{\circ} \mathrm{C}$. Bacterial suspension was prepared by adding $20 \mathrm{ml}$ of sterile distilled water per plate and scraping the growth with a wire loop. The bacterial suspensions were optically [at $560 \mathrm{~nm}$ ] adjusted to give $10^{8}$ colony forming units (cfu) per milliliter. Bacterial inoculum was mixed with the soil thoroughly ten days before planting.

\section{Seed tubers and sowing}

Diamant, Desiree, Herms, Lady Joy, Lady Rossetta, Nicola, Spunta and Valor potato tubers were obtained from Vegetable Research Department, Horticulture Res. Instit. ARC. Sterilized pots (30 $\mathrm{cm}$ in diam.) containing $5 \mathrm{~kg}$ sandy loam soil were infested with $R$. solanacearum bacteria by adding $250 \mathrm{ml}$ of bacterial suspension for each pot. Five pots [one tuber/pot] were used for each treatment and replicated five times.

\section{Treatments}

Four factors namely cultivars, fertilizers, bioagents and inducers were tested independently to study their effect on brown rot control using aforementioned procedures in "Seed tubers and sowing" :

\section{Cultivars}

Susceptibility of eight cultivars previously mentioned were evaluated in pot experiments against bacterial wilt disease.

\section{Chemical fertilizers}

Ammonium sulfate [20.6\% N], potassium sulfate $[47 \% \mathrm{~K}]$, Urea $[46.5 \% \mathrm{~N}]$ and calcium superphosphate $[15 \% \mathrm{P}]$ were applied as a single application at a rate of $1 \mathrm{~g} /$ pot. These amendments were added 7 days before planting to the potted soil.

\section{Bioagents}

Isolates of Bacillus subtilis, Pseudomonas putida and $P$. fluorescens were isolated from the rhizosphere soil of potato plants at different prov- inces and completely identified according to Bergey's Manual of Systematic Bacteriology (Krieg and Holt 1984). The first two suppressive isolates were grown in nutrient glucose broth medium at $29^{\circ} \mathrm{C}$ for $48 \mathrm{hrs}$ but the third one was grown in King's medium at $29^{\circ} \mathrm{C}$ for $72 \mathrm{hrs}$. The growth of these bioagents were optically standardized $\left(10^{9}\right.$ $\mathrm{cfu} / \mathrm{ml}$ ) and used for tubers treatment. Potato tubers were dipped in suspension of each bioagent for one hr just before sowing [Tawfik et al 2001].

\section{Chemical inducers}

Salicylic acid (2-hydroxybenzoic acid, $\mathrm{C}_{7} \mathrm{H}_{6} \mathrm{O}_{3}$ ), di-potassium hydrogen phosphate $\left(\mathrm{K}_{2} \mathrm{HPO}_{4}\right)$ and tri-potassium phosphate $\left(\mathrm{K}_{3} \mathrm{PO}_{4}\right)$ were applied singly at $1 \mathrm{mM}$ [Zayed et al 2004]. These agents were sprayed as foliar treatment three times though the experiment each 20 days from sowing.

\section{Integrated treatment}

The same aforementioned four experiments were repeated using only the best treatment resulted from each, in addition combination between them. Valor cultivar was used in control treatment.

\section{Disease assessment}

Disease severity was assessed 80 days after planting according to the key proposed by Kempe and Sequeira 1983. Percentage of infected tubers and yield per plant were recorded 105 days after planting. Results were statistically analyzed, and L.S.D. (0.05 level) was calculated according to Cochran and Cox 1957.

\section{RESULTS}

\section{Effect of different applications on controlling brown rot disease incidence of potato:}

\section{a. Cultivars}

Data in Table (1) show that the eight potato cultivars were all infected with potato brown rot. Herms cv. was the least susceptible $(26.2 \%$ of infection) followed by Nicola $(31.9 \%)$ and Diamant $(39.7 \%)$, respectively. Valor, on the other hand, was highly susceptible $(90.1 \%)$ followed by Spunta (84.9\%) and Lady Joy (73.8\%), respectively. Desiree (50.3\%) and Lady Rossetta (62.4\%) cvs. were moderate in this concern. 
Table 1. Susceptibility of potato cultivars to brown rot disease under artificial inoculation conditions

\begin{tabular}{|c|c|c|c|c|}
\hline \multirow[b]{2}{*}{ Cultivars } & \multirow{2}{*}{$\begin{array}{c}\text { Infection }^{(1)} \\
(\%)\end{array}$} & \multirow{2}{*}{$\begin{array}{c}\text { Disease severity } \\
(\%)\end{array}$} & \multicolumn{2}{|c|}{ Yield $^{(2)}$} \\
\hline & & & Tubers No. & Tubers weight (g) \\
\hline Herms & 26.2 & 20.5 & 10.8 & 97.3 \\
\hline Nicola & 31.9 & 25.3 & 10.2 & 92.1 \\
\hline Diamant & 39.7 & 31.3 & 9.3 & 80.3 \\
\hline Desiree & 50.3 & 42.6 & 7.9 & 73.5 \\
\hline Lady Rossetta & 62.4 & 50.8 & 7.2 & 66.2 \\
\hline Lady Joy & 73.8 & 59.1 & 5.9 & 60.4 \\
\hline Spunta & 84.9 & 67.4 & 5.3 & 53.7 \\
\hline Valor & 90.1 & 75.2 & 4.5 & 37.9 \\
\hline L.S.D. at 0.05 & 4.9 & N.S & N.S & 3.6 \\
\hline
\end{tabular}

(1) Percentage of infected tubers.

(2) Calculated as an average number and weight of tubers per plant.

\section{b. Chemical fertilizers}

Results in Table (2) show that using fertilizers significantly reduced the disease incidence compared with the control. Calcium superphosphate was the most effective one followed by potassium sulfate, Urea and ammonium sulfate, respectively. Percentages of infection were $40.6 \%, 48.3 \%$, $55.4 \%$, and $71.9 \%$ for the aforementioned treatments, respectively.

\section{c. Bioagents}

Table (3) shows that treatment of seed tubers with Pseudomonas fluorescens, Ps. putida and Bacillus subtilis are all effective in controlling bacterial wilt disease. The three isolates significantly reduced disease incidence compared with the control (96.4\% infection). Ps. putida was the most effective antagonists against the investigated pathogen $(47.7 \%)$ followed by Ps. fluorescens $(61.9 \%)$ and B. subtilis $(73.2 \%)$, respectively.

\section{d. Chemical inducers}

Foliar treatment of di-potassium phosphate, salicylic acid and tri-potassium phosphate significantly reduced the disease incidence when compared with the control treatment (Table 4). The percentages of infection were $50.6 \%, 69.8 \%$ and $85.3 \%$ for tri-potassium phosphate, salicylic acid and di-potassium phosphate, respectively.

\section{e. Integrated treatment}

Table (5) shows the multiple effect of cultivar, the fertilizer, the bioagent and the inducers. The relevant data here did not vary than those recorded in the aforementioned experiments with the data presented in Tables (1, 2, 3 and 4). These were true when they were applied separately, however the case was greatly differed when they were applied in combination. This application gave higher effectiveness than the single one. As example, the percentage of infection was greatly reduced in combination treatment to reach $22.5 \%$, which could not be compared to those of the check treatment where the corresponding figure was $95.1 \%$. This given reduction was more superior than those of the single treatment.

In all previous experiments, it could be noticed that disease severity had the same trend of the infection. Also, yield increased when compared with the control treatment.

\section{DISCUSSION}

Cultivar reaction experiments had proven that used potato cultivars varied in their susceptibility to brown rot disease. Herms, Nicola and Diamant were the most tolerant, respectively. Contrariwise, Valor, Spunta and Lady Joy were the most susceptible, respectively. Meanwhile, Desiree and Lady Rossetta showed intermediate susceptibility. Difference in susceptibility of potato cultivars to 
Table 2. Effect of chemical fertilizers on the disease incidence and yield of potato under artificial inoculation conditions

\begin{tabular}{|c|c|c|c|c|}
\hline \multirow[b]{2}{*}{ Chemical fertilizers } & \multirow{2}{*}{$\begin{array}{c}\text { Infection }^{(1)} \\
(\%)\end{array}$} & \multirow{2}{*}{$\begin{array}{l}\text { Disease severity } \\
\qquad(\%)\end{array}$} & \multicolumn{2}{|c|}{ Yield $^{(2)}$} \\
\hline & & & Tubers No. & $\begin{array}{c}\text { Tubers weight } \\
\text { (g) }\end{array}$ \\
\hline Calcium superphosphate & 40.6 & 31.5 & 9.3 & 74.1 \\
\hline Potassium sulfate & 48.3 & 39.7 & 8.6 & 68.4 \\
\hline Urea & 55.4 & 47.2 & 8.0 & 60.6 \\
\hline Ammonium sulfate & 71.9 & 64.8 & 7.1 & 40.9 \\
\hline Control & 96.4 & 85.8 & 3.0 & 25.2 \\
\hline L.S.D at 0.05 & N.S & 6.8 & N.S & 5.1 \\
\hline
\end{tabular}

(1) Percentage of infected tubers.

(2) Calculated as an average number and weight of tubers per plant.

Table 3. Effect of different bioagents on incidence of potato brown rot disease and yield under artificial inoculation conditions

\begin{tabular}{|lcccc|}
\hline & & & \multicolumn{2}{c|}{ Yield $^{(2)}$} \\
\cline { 4 - 5 } \multicolumn{1}{c}{ Bioagents } & $\begin{array}{c}\text { Infection }^{(1)} \\
\text { (\%) }\end{array}$ & $\begin{array}{c}\text { Disease severity } \\
(\%)\end{array}$ & Tubers No. & $\begin{array}{c}\text { Tubers weight } \\
(\mathrm{g})\end{array}$ \\
\hline Pseudomonas putida & 47.7 & 38.4 & 6.7 & 60.2 \\
Ps. fluorescens & 61.9 & 47.8 & 6.0 & 53.8 \\
Bacillus subtilis & 73.2 & 59.1 & 5.4 & 39.5 \\
\hline Control & 96.4 & 85.8 & 3.0 & 25.2 \\
\hline L.S.D at 0.05 & 9.8 & 6.3 & N.S & 5.1 \\
\hline
\end{tabular}

(1) Percentage of infected tubers.

(2) Calculated as an average number and weight of tubers per plant

Table 4. Effect of foliar spraying with different inducers on incidence of potato brown rot disease and yield under artificial inoculation conditions

\begin{tabular}{|c|c|c|c|c|}
\hline \multirow[b]{2}{*}{ Inducers } & \multirow{2}{*}{$\begin{array}{l}\text { Infection }^{(1)} \\
\quad(\%)\end{array}$} & \multirow{2}{*}{$\begin{array}{c}\text { Disease severity } \\
(\%)\end{array}$} & \multicolumn{2}{|c|}{ Yield $^{(2)}$} \\
\hline & & & Tubers No. & $\begin{array}{c}\text { Tubers weight } \\
(\mathrm{g})\end{array}$ \\
\hline Tri-potassium phosphate & 50.6 & 41.2 & 4.9 & 51.3 \\
\hline Salicylic acid & 69.8 & 56.5 & 4.3 & 45.7 \\
\hline Di-potassium phosphate & 85.3 & 70.1 & 3.9 & 38.2 \\
\hline Control & 96.4 & 85.8 & 3.0 & 25.2 \\
\hline L.S.D at 0.05 & 10.3 & 9.4 & N.S & 4.2 \\
\hline
\end{tabular}

(1) Percentage of infected tubers.

(2) Calculated as an average number and weight of tubers per plant. 
Table 5. Effect of the best agents singly and in combination on incidence of potato brown rot disease and yield under artificial inoculation conditions

\begin{tabular}{|lcccc|}
\hline & Infection $^{(1)}$ & Disease severity & \multicolumn{2}{c|}{ Yield $^{(2)}$} \\
\cline { 4 - 5 } Agents & $(\%)$ & $(\%)$ & Tubers No. & $\begin{array}{c}\text { Tubers } \\
\text { weight (g) }\end{array}$ \\
\hline Herms cv. (A) & 28.5 & 21.9 & 10.1 & 91.3 \\
Calcium superphosphate (B) & 41.9 & 28.7 & 8.9 & 79.4 \\
Pseudomonas putida (C) & 50.1 & 41.6 & 7.0 & 63.2 \\
Tri-potassium phosphate (D) & 56.2 & 47.8 & 5.7 & 49.4 \\
A + B + C + D & 22.5 & 17.5 & 10.9 & 98.1 \\
\hline Control & 95.1 & 79.4 & 3.3 & 23.5 \\
\hline L.S.D at 0.05 & 4.8 & 3.3 & N.S & 6.2 \\
\hline
\end{tabular}

(1) Percentage of infected tubers.

(2) Calculated as an average number and weight of tubers per plant.

brown rot disease was confirmed by Farag 1976, Vasilieva 1998, Wiles 2001 and Nemeth et al 2002. Differences between cultivar in susceptibility might be due to the differences in their genetic constitutions and characters correlated to this genetic structure [Walker 1975].

Soil amendment with chemical fertilizers exerted a positive effect on the brown rot disease control compared. Application of calcium superphosphate was the most effective treatment followed by potassium sulfate, Urea and ammonium sulfate, respectively. These results are accordance with those of Wiles 2001, Abd El-Ghafar \& Abd El-Sayed 2002, Kelaniyangoda et al 2002 and Farag et al 2006. In this concern, Michel and Mew 1998 reported that bacterial wilt of tomato was significantly decreased with application of Urea or calcium oxide due to their effect on population dynamic of the pathogen and on soil $\mathrm{pH}$ values.

An alternative control measures such biological control have been investigated which is based on microbial antagonism depends on competition or antibiosis. Certain bacteria like Pseudomonas fluorescens, Ps. putida and Bacillus subtilis have been found to delay the development and reduce incidence of bacterial wilt disease. The highest efficiency for controlling the disease was showed in Ps. putida isolate followed by Ps. fluorescens and $B$. subtilis ones. These results are in harmony with those of Dhanbir \& Rana 2000 and Tawfik et al 2001.
Induced systemic resistance (ISR) has proven a promising efficiency in controlling bacterial wilt in tomato (Abd El-Sayed et al 1996) and in potato (Zayed et al 2004). Efficiency of disease resistance mechanisms could be expressed systemically for extended periods of times by using chemicals which themselves were not antimicrobial [Kuc 1993]. Application of di-potassium phoisphate, salicylic acid and tri-potassium phosphate singly as chemical agents, reduced the disease incidence when they were applied as foliar treatment three times during crop growth, where percentage of infection was $85.3 \%, 69.8 \%$ and $50.6 \%$ for each inducer, respectively. These results conform with the findings of Zayed et al 2004.

The combined experiment, in which the best agent of each tested group was evaluated. It was proved that the combination between them resulted the most effective on the disease incidence. Therefore, it could be said that such integrated management was more of less the best way of competing potato bacterial wilt disease. The superiority of this programme may be attributed to the combining different mode of action for the tested agents.

In all previous experiments, there was a positive correlation between percentage of infection and disease severity. Also, the yield increased compared with the control treatment. Whereas, the lowest yield was obtained with control, this might be reflected on the effect of the disease on the growth of plants. 
Eventually, it could be advised to use such a programme to fulfill high disease management and to avoid the hazardous risk of the toxic bactericides on the public health and the environment as well.

\section{REFERENCES}

Abd El-Ghafar, N.Y. and W.M. Abd El-Sayed (2002). Evaluation of fertilization and organic treatments on controlling potato bacterial wilt disease. Arab Universities Journal of Agricultural Sciences, 10(3): 1071-1085.

Abd El-Sayed, Wafaa M.; N.Y. Abd El-Ghafar and S.A.M. Shehata (1996). Application of salicylic acid and aspirin for induction of resistance to tomato plants against bacterial wilt and its effect on endogenous hormones. Annals of Agriculture Science, Ain Shams University, Cairo, 41: 10071020.

Cochran, W.C. and G.N. Cox (1957). Experiment Design, $2^{\text {nd }}$ Ed., p. 26. Wiley and Sons. Inc., N.Y.

Dhanbir, S. and S.K. Rana (2000). Biocontrol of bacterial wilt of potato. J. of Mycology and Plant Pathology, 30(3): 420-421.

Farag, N.S. (1970). Studies on Brown Rot of Potato in Egypt, pp. 73-78. M.Sc. Thesis, Fac. Agric., Ain Shams Univ., Cairo.

Farag, N.S. (1976). Interaction Between Some Soil Microflora and Pseudomonas solanacearum, pp. 65-67. Ph.D. Thesis, Fac. of Agric., Ain Shams University, Cairo.

Farag, N.S.; D.E. Stead and J.D. Janse (1999). Ralstonia solanacearum race 3 , biovar 2 , detected in surface (irrigation) water in Egypt. J. Phytopathol. 147: 485-487.

Farag, N.S.; M.S. Mikhail and Mary G. Gerges (2006). Further observation on the bacteriology and pathology of Ralstonia solanacearum. Egypt. J. Agric. Res., 84(6): 1679-1683.

Kelaniyangoda, D.B.; S.K. Tharmarajah and L.G. Herath (2002). Bacterial wilt management in potato rooted stem cuttings in the net-hose Tropical Agriculturist, 151: 53-58.

Kempe, J. and L. Sequeira (1983). Biological control of bacterial wilt of potato. Plant Dis., 67: 499-503.
Krieg, N.R. and J.G. Holt (1984). Bergey's Manual of Systematic Bacteriology, pp. 141214, Williams and Wilkins, Baltimore, USA.

Kuc, J. (1993). Non pesticide control of plant disease. Proc. 10 ${ }^{\text {th }}$ International Symp. On Systemic Fungicides and Antifungal Compounds, Eugen Ulmer, Stuttgart, pp. 225-237.

Lemaga, B.; D. Siriri and P. Ebanyat [2001]. Effect of soil amendments on bacterial wilt incidence and yield of potato in Southwestern Uganda. African Crop Science Journal, 9[1]: 267278.

Michel, V.V. and T.W. Mew (1998). Effect of soil amendment on the survival of Ralstonia solanacearum in different soils. Phytopathology, 88: 300-305.

Milling, A.; A. Lembke; J. Schonfeld and K. Smalla (2004). Survival and activity of the Ralstonia solanacearum antagonist Pseudomonas chlororaphis in the rhizosphere of tomato and its impact on the indigenous bacterial community. Bulletin-OILB/SROP, 27(1): 177-186.

Nemeth, J.; A. Kovacs; F. Mero and M. Molnar (2002). Occurrence of bacterial brown rot of potato in Hungary. Novenyvedelem, 38(9): 453-461. [c.f. Rev. Plant Pathol., 82(4): 444].

Tawfik, A.E.; A.I. Hanna; L.A. El-Ghareeb; A.A. Gommah and S.M. Mahmoud (2001). Applied approach for controlling brown rot and soft rot bacteria of potatoes. J. Agric. Sci. Mansoura Univ., Egypt, 26(6): 3631-3642.

Vasilieva, S.V. (1998). Brown bacterial rot of potato. Zashchita Karantin Rastenil, 11: 34-35. [c.f. Rev. Plant Pathol., 79 (10): 1017].

Walker, J.C. (1975). Plant Pathology, $3^{\text {rd }}$ Ed. 707 pp. McGraw Hill Book Company, Inc. New York.

Wiles, G. (2001). Potato production in PNG: the contribution of research to alleviating constraints to potato production. Food and Nutrition Conference, PNG University of Technology, Papua New Guinea, 26-30 June: 792-806.

Zayed, K.A.M.; N.Y. Abd El-Ghafar; I.H. ElAbbasi and F.M. Abo El-Abbas (2004). Integration between abiotic and biotic agents to control potato bacterial wilt disease. Arab Universities Journal of Agricultural Sciences, 12(1): 447457. 